\title{
PELATIHAN PEMBUATAN TEPUNG CACING TANAH SEBAGAI BAHAN TAMBAHAN BERPROTEIN TINGGI DALAM UPAYA MEMPERKUAT EKONOMI MASYARAKAT
}

\author{
Oleh: \\ I Gusti Made Sanjaya ${ }^{1}$, Samik', Toeti Koestiari ${ }^{3}$ \\ 1,2,3 Jurusan Kimia FMIPA Unesa \\ 1igmasanjaya@gmail.com
}

\begin{abstract}
Abstrak
Telah dilakukan PKM pembuatan tepung cacing tanah pada ibu-ibu PKK RT 2 RW 3 Desa Sumberdukun Ngariboyo Magetan sebagai alternatif penghasilan tambahan dalam membantu pendapatan suami di bidang pertanian. PKM dilakukan dengan metode pelatihan dengan keberhasilan diukur melalui monitoring lapangan dan angket survey. Hasilnya menunjukkan bahwa PKM berjalan dengan baik dan efektif yang ditunjukkan dengan keterampilan peserta menghasilkan tepung cacing tanah berkualitas yang dapat dilihat dari produk tepung yang dihasilkan. Peserta dapat menyerap bekal manajemen bahan, manajemen usaha serta kewirausahaan dengan baik.
\end{abstract}

Kata Kunci: Cacing Tanah, Pelatihan, Tepung,

\begin{abstract}
We performed the Community Services related to the manufacture of flour earthworms by using targets are the ladies of PKK members in RT 2 RW 3 Sumberdukun village Ngariboyo Magetan as an alternative to additional income to help their husbands in agriculture. The Community Services is done with training method and it success is measured by field monitoring and using a questionnaire survey. The result show that the Community Services running properly and effectively. This is shown by the participant skills to produce quality flour of earthworms. It can be seen from the resulting flour products. The participants can understand training materials management, business management, and entrepreneurship well.
\end{abstract}

Keywords: earthworms, training, flour.

\section{PENDAHULUAN}

Penduduk RT 2 RW 3 Desa Sumberdukun Kecamatan Ngariboyo Kabupaten Magetan sebagian besar berprofesi sebagai petani. Para ibu rumah tangga di daerah tersebut pada waktu-waktu tertentu diperlukan membantu suami di areal sawah pertanian. Namun, sebagian besar waktu mereka merupakan waktu luang yang dihabiskan hanya dengan mengobrol atau menonton acara televisi. Kondisi ini sangat tidak produktif sehingga penghasilan rata-rata keluarga cukup kecil dan hanya cukup untuk kebutuhan makan sehari-hari.

Ibu-ibu RT 2 Rw 3 Desa Sumberdukun Kecamatan Ngariboyo Kabupaten Magetan yang ingin membantu para suami memperoleh tambahan nafkah keluarga, mencoba memohon bantuan pada Jurusan Kimia FMIPA Universitas Negeri Surabaya untuk mencarikan alternatif peluang usaha guna mengisi waktu luang. Sebagai masyarakat ilmiah yang memiliki kewajiban melaksanakan tridarma perguruan tinggi antara lain pengabdian kepada masyarakat, maka Jurusan Kimia FMIPA Unesa setelah membentuk tim untuk mengatasi kebutuhan masyarakat tersebut dan melakukan survey lapangan ke Desa Sumbersukun.

Berdasarkan survey lapangan, para keluarga petani berpotensi besar untuk berbudidaya cacing tanah jenis Lumbricus rubellus. Potensi inilah yang kemudian dikemas sebagai alternatif peluang usaha potensial yang dikembangkan bagi ibu-ibu rumah tangga di Desa Sumberdukun tersebut yaitu usaha pembuatan tepung cacing tanah.

Cacing tanah memiliki nutrisi relatif tinggi dengan kadar protein mencapai lebih dari $50 \%$ berat kering (Esha, 2014). Cacing tanah juga memiliki enzim lumbrokinase yang dapat meluluhkan lemak jahat dalam pembuluh darah untuk melancarkan peredaran darah. Kandungan antibakteri dari cacing tanah dapat membunuh Escherichia colli, Shigella dysenterica, Staphylococcus aureus, dan Salmonella thypi. Kandungan dari asam- 
asam aminonya dapat meningkatkan daya tahan tubuh.

Pembuatan tepung cacing tanah dipakai alternatif berdasarkan pertimbangan pembuatannya yang relatif sangat mudah dan dapat dilakukan dalam skala home industry atau skala rumah tangga (Anonim, 2015; Aisyah, dkk, 2000; Toto dan Jumsih, 2000). Berdasarkan informasi di atas, cacing tanah jenis Lumbricus rubellus juga memiliki kandungan nutrisi relatif tinggi sehingga sangat baik dikembangan sebagai suplemen vitalitas dan memiliki potensi untuk dikembangkan sebagai bahan obat, seperti: obat hipertensi, stroke, dan tipus (Herdian, 2010).

\section{METODE PELAKSANAAN}

PKM pembuatan tepung cacing tanah dilaksanakan oleh Tim Pelaksana PKM FMIPA Unesa Surabaya dengan cara melatihkan keterampilan dalam membuat tepung cacing pada ibu-ibu RT 2 Rw 3 Desa Sumberdukun Ngariboyo Magetan melalui pendampingan. Keterampilan yang dilatihkan tersebut dikembangkan sebagai peluang usaha pembuatan tepung cacing tanah melalui pelatihan, pembinaan dan monitoring. Respon peserta terhadap kegiatan pelatihan telah diperoleh dengan penyebaran angket respon pada peserta pelatihan.

Jurusan Kimia FMIPA Unesa sebagai Tim Pelaksana PKM dalam memfasilitasi pengembangan produksi tepung cacing tanah hasil wirausaha ibu-ibu RT 2 RW 3 Desa Sumberdukun juga merintis jalinan kerjasama dengan pihak Komunitas Agro Harmonie (KAH) yang berperan sebagai pembeli produk tersebut kalau produksi tepung cacing telah berhasil dengan skala besar. Diharapkan dengan kegiatan pelatihan tersebut, ibu-ibu peserta lebih berdaya dan lebih produktif sehingga mampu memperkuat ekonomi masyarakat.

\section{HASIL DAN PEMBAHASAN}

Kegiatan PKM telah dilaksanakan pada hari Minggu tanggal 7 Juni 2015. Kegiatan awal dalam bentuk pelatihan mencakup pemberian materi dilakukan di lantai 2 dan lantai 1 ruang pertemuan masjid RT 2 RW 3 Desa Sumberdukun Magetan. Tahapan pelaksanaan PKM berikutnya adalah pelatihan pembuatan tepung cacing, dan seterusnya sebagaimana dapat dilihat gambar-gambar sebagai berikut.

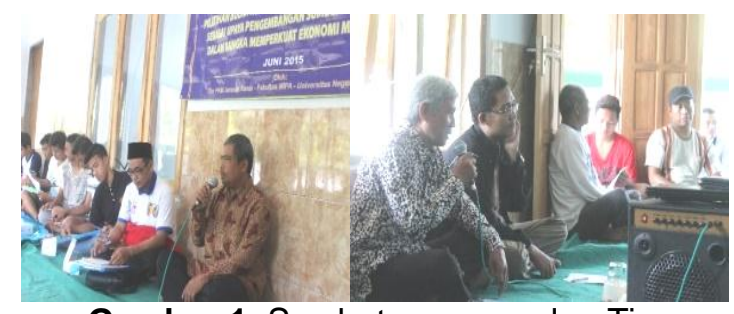

Gambar 1. Sambutan warga dan Tim

Pelaksana PKM Unesa pada Pembukaan Kegiatan PKM

Pada tahap awal pelaksanaan PKM diisi dengan sambutan-sambutan yang dilakukan oleh Ketua RT 2 RW 3 Desa Sumberdukun Magetan yang mewakili tuan rumah dan wakil dari tim Pelaksana PKM (Gambar 1). Pada kesempatan tersebut dibagikan kit pelatihan yang telah disiapkan oleh Tim Pelaksana PKM kepada para peserta pelatihan, seperti terlihat pada Gambar 2.

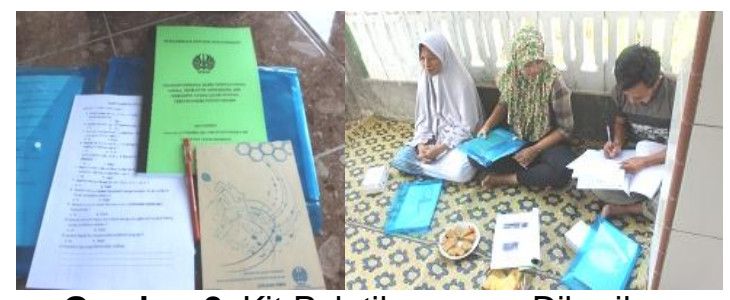

Gambar 2. Kit Pelatihan yang Diberikan kepada Peserta

Pelaksanaan pelatihan diikuti secara antusias oleh para peserta. Ibu-ibu peserta tidak ada yang meninggalkan lokasi selama pelatihan berlangsung. Metode interaktif yang diterapkan memungkinkan mereka terlibat langsung dalam pelaksanaan pelatihan dengan cara bertanya jawab maupun praktek langsung dalam pembuatan tepung cacing.

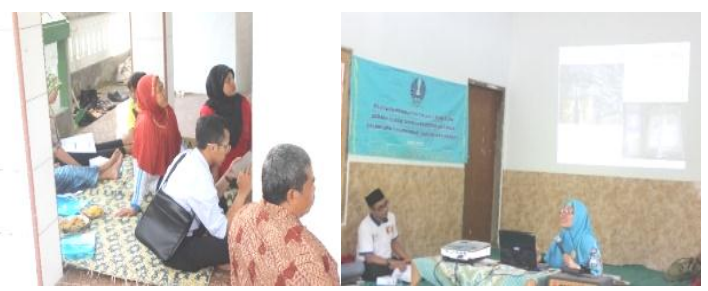

Gambar 3. Kegiatan workshop pembuatan tepung cacing

Narasumber pelatihan yang diundang saat itu adalah Dr. Titik Taufikurohmah yang memberikan segenap pengetahuannya saat pembuatan tepung cacing kepada peserta, seperti ditunjukkan pada Gambar 3. 


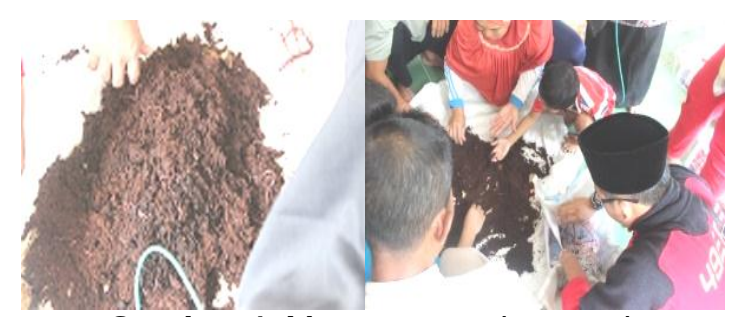

Gambar 4. Memanen cacing tanah

Pelatihan disamping dilakukan dengan pemaparan materi dengan bantuan media power point, juga dilakukan dengan pemberian contoh dan praktek langsung mulai dari memanen cacing, menjadikan bahan baku cacing kering yang siap untuk dijadikan tepung cacing, seperti terlihat pada Gambar 4, 5 , dan 6.

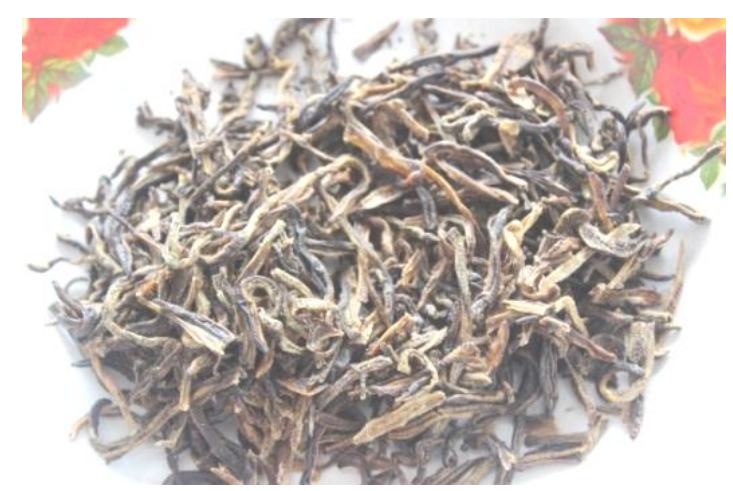

Gambar 5. Pengeringan cacing sehingga jadi bahan baku kering tepung cacing

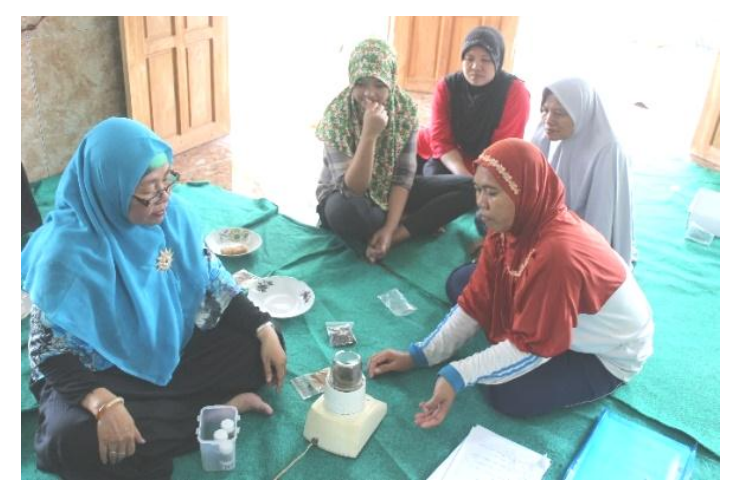

Gambar 6. Pendampingan pembuatan tepung cacing

Tepung cacing yang dihasilkan melalui pelatihan berwarna agak kemerahan. Tepung tersebut kemudian dikemas plastik kedap air agar tepung cacing bisa awet dalam penyimpanannya, terlihat pada Gambar 7.

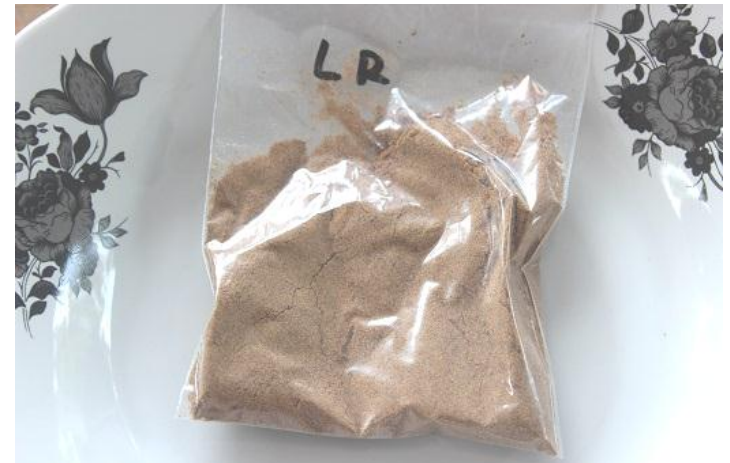

Gambar 7. Tepung cacing hasil pelatihan yang baru dihasilkan dan yang sudah dikemas dalam plastik

Lebih lanjut agar ada variasi produk, ibuibu peserta juga dilatih untuk mengemas tepung cacing yang tidak hanya dalam kemasan plastic, tetapi lbu-ibu peserta dilatih juga mengemas tepung cacing dalam kapsul. Memang pada awalnya terasa cukup susah memasukkan tepung cacing ke dalam kapsulkapsul kecil melalui lubang dari kapsul yang cukup sangat kecil pula, seperti terlihat pada Gambar 8 berikut.

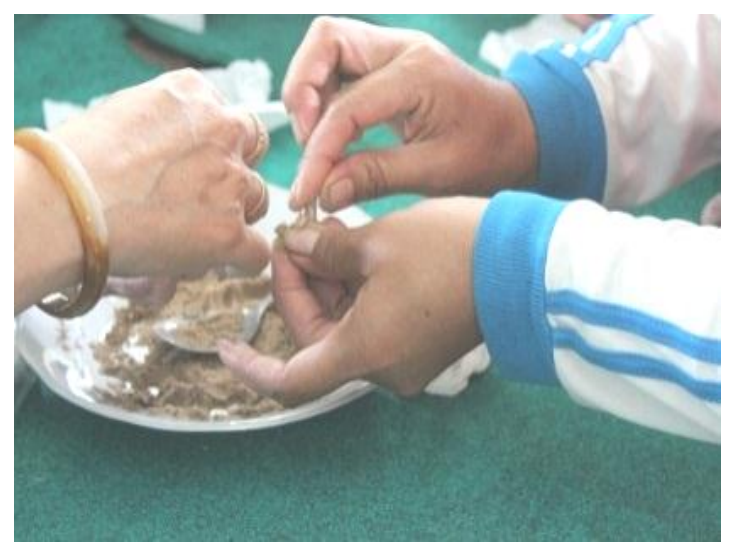

Gambar 8. Pendampingan pembuatan variasi produk kapsul cacing

Disamping pelatihan pengelolaan bahan baku dan produksi tepung cacing, para ibu peserta juga diberikan wawasan tentang prospek usaha tepung cacing maupun pemasarannya, seperti tercantum pada Gambar 10. 


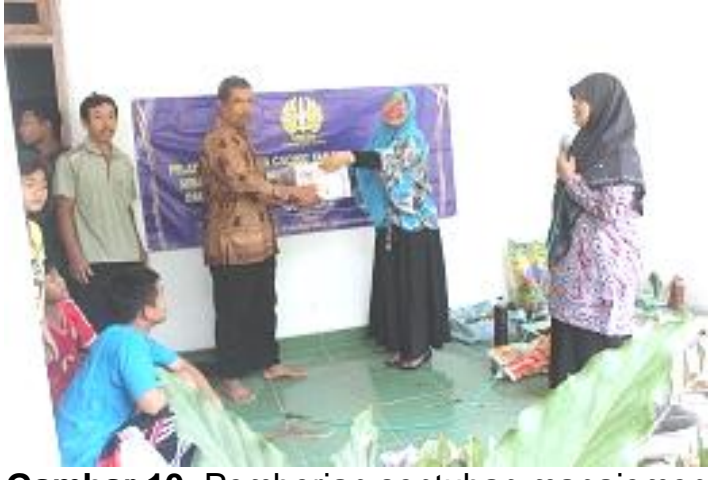

Gambar 10. Pemberian sentuhan manajemen pemasaran produk

Sebagai gambaran usaha, setiap $1 \mathrm{~kg}$ cacing dapat dibuat menjadi 800 gram tepung cacing. Cacing segar dijual dengan harga Rp. $30.000,00$ per-kilogram. Adapun kalau ditepungkan, harga tepung cacing bisa mencapai Rp 120.000,00 per kilogram. Sebagai perkiraan, dengan modal $2 \mathrm{~kg}$ cacing dapat dihasilkan $1,6 \mathrm{~kg}$ tepung cacing. Dengan demikian, harga jual berubah dari Rp 60.000 menjadi Rp. 192.000,00. Pihak Unesa Surabaya juga menunjukkan bahwa kalau produksi bagus, tim mampu menghubungkan hasil produksi ibu-ibu peserta dengan pihak Komunitas Agro Harmonie (KAH) sebagai pihak pembeli produk tepung cacing dalam sekala besar.

Hasil angket respon peserta terhadap pelatihan pembuatan tepung cacing dapat dilihat pada tabel 1 berikut.

Tabel 1. Rekap angket respon peserta pelatihan budidaya cacing tanah

\begin{tabular}{llcc}
\hline \multicolumn{1}{c}{ Pernyataan } & \multicolumn{2}{c}{ Jawaban } \\
\cline { 3 - 4 } & \multicolumn{1}{c}{ ya } & tidak \\
\hline 1. & $\begin{array}{l}\text { Apakah bapak lbu pernah mendapat pelatihan pembuatan } \\
\text { tepung cacing tanah Lumbricus rubellus? }\end{array}$ & 9 & 11 \\
\hline $\begin{array}{l}\text { Apakah menurut Bapak Ibu pelatihan pembuatan tepung cacing } \\
\text { tanah Lumbricus rubellus mudah dikerjakan? }\end{array}$ & 16 & 4
\end{tabular}

$\begin{array}{llll}\text { 3. Apakah menurut Bapak Ibu pelatihan ini bermanfaat? } & 20 & 0\end{array}$

4. Apakah menurut Bapak Ibu tertarik mengembangkan produk $\quad 20 \quad 0$ tepung cacing tanah Lumbricus rubellus?

\begin{tabular}{llll}
\hline 5. & Apakah Bapak lbu menghendaki pelatihan yang lain? & 15 & 5
\end{tabular}

6. Pelatihan Apa yang dikehendaki, tuliskan!

- Pelatihan pembuatan tepung dari cacing jenis lain

- Pelatihan pembuatan herbal dan pakan dari cacing

- Pelatihan manajemen budidaya cacing

- Pelatihan budidaya burung

- Pelatihan budidaya tanaman / sayur

- Pelatihan pembuatan kopi cacing

- Pelatihan budidaya tanaman obat

Dari hasil angket tersebut dapat dibaca bahwa masyarakat cukup berpandangan positif terhadap pelaksanaan PKM pembuatan tepung cacing dan berharap dapat mengembangkan variasi produk dari tepung cacing tersebut.

Monitoring terhadap perkembangan kemampuan masyarakat dalam pengembangan produk tepung dan budidaya dan variasi produk cacing tanah dilakukan dalam waktu beberapa minggu setelah pelatihan dan pendampingan diselesaikan untuk mengetahui perkembangan kemampuan masyarakat menyerap materi yang pernah dilatihkan seperti ditunjukkan pada gambar 11 berikut. 


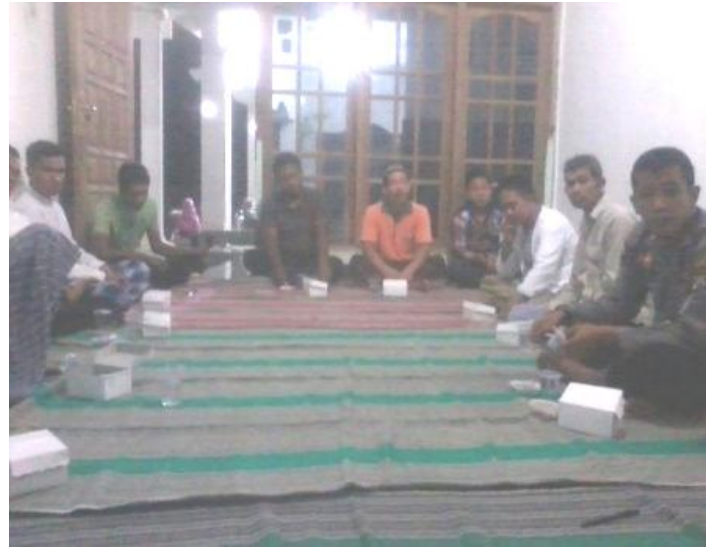

Gambar 11. Suasana Monitoring dan Evaluasi Perkembangan Budidaya Cacing Tanah

Pada kegiatan ini diperoleh permasalahanpermasalahan yang dihadapi oleh para peserta pelatihan antara lain: 1) matinya cacing karena kering atau media kurang air, 2) hilangnya cacing karena dimakan tikus, 3) hilangnya cacing karena dimakan kadal, 4) hilangnya cacing karena dimakan katak, 5) hilangnya cacing karena keluar dari media, 6) media yang terlalu padat, 7) cacing dikerumuni semut, 8) cacing kurus-kurus, 9) kurang waktu untuk memilah, 10) penjemuran yang kurang memadai sehingga kekeringan bahan dasar tepung cacing tidak baik, dan 12) lebih mempercepat hasil dengan menjual cacing untuk umpan pancing daripada diproduksi menjadi tepung cacing.

Untuk permasalahan tersebut maka tim Pelaksana PKM memberikan solusi secara umum antara lain: 1) media cacing tidak boleh kering jika terlihat kering segera disiram dengan air, 2) untuk hama tikus, kadal, katak atau semut maka kandang bisa digantung dan ditaburi kapur semut dibawah sehingga semut tidak naik dan ditambah juga dengan jebakan tikus, 3) jika cacing keluar dari media artinya cacing tidak cocok dengan medianya maka media harus diganti atau diberi lampu karena cacing tidak suka dengan cahaya atau suasana terang karena jika kena terang dia akan masuk, 4) jika media terlalu padat maka perlu diurai, 5) agar lebih gembur perlu memasukkan oksigen ke dalam tanah, 6) jika cacing kurus-kurus kemungkinan makanan tidak cocok maka makanan bisa diganti dengan yang lain yang kaya protein, 7) cacing hendaknya dipilah antara yang kecil dan yang besar sehingga dapat ditentukan mana yang bibit dan afkir sehingga dapat menentukan mana yang bisa dijual langsung sebagai pakan sebagai bibit atau dijadikan bahan tepung.

Secara umum tim Pelaksana PKM menyarankan untuk belajar dan mengamati perkembangan cacing setiap hari walaupun hanya 2 menit untuk mengecek kondisi cacing. Dengan demikian, jika ada hama segera dapat diketahui dan segera diatasi. Tim Pelaksana PKM juga menyarankan supaya peserta tidak menjual dalam bentuk cacing hidup tetapi menjadikan cacing tanah sebagai minimum pembentuk kompossing baik komposcing padat maupun cair. Hal ini sangat bagus dipakai pengganti pupuk kimia sehingga mengurangi biaya pupuk untuk pertanian. Tim Pelaksana PKM juga menyarankan supaya cacing dijual dalam bentuk tepung cacing karena cacing hidup sangat beresiko di perjalanan, yaitu resiko mati dan resiko turun bobot. Disamping itu, juga menyarankan untuk membentuk komunitas atau paguyupan pembudidaya cacing yang sering bertemu untuk sharing dan berbagi pengalaman budidaya cacing sebagai motivasi dan menambah wawasan. Hal ini dalam jangka panjang juga akan menguntungkan karena penjualan cacing lebih terkendali.

\section{SIMPULAN DAN SARAN}

PKM pembuatan tepung cacing tanah yang dilaksanakan dengan melakukan pelatihan bagi ibu-ibu RT 2 RW 3 Desa Sumberdukun Magetan telah berjalan sangat baik dengan ditunjukkan bahwa ibu-ibu peserta telah mampu dan terampil membuat tepung cacing, mengemasnya dalam kemasan plastik maupun dalam kapsul-kapsul tepung cacing. Ibu-ibu peserta juga mendapat wawasan peluang dalam berwirausaha dan memasarkan tepung cacing tanah. Untuk hal tersebut para ibu peserta memberikan respon yang sangat baik terhadap kegiatan PKM.

\section{DAFTAR PUSTAKA}

Anonim,http://perawatanternakbudidaya.blogs pot.com/2014/05/jenis-jenis-cacingtanah-dan-tempat-hidupnya.html, diakses tanggal 26 Februari 2015.

Aisyah, S. D., Mustofa, D.A., dan Jumsih. 2000. Kandungan hara N, P, K Kascing Lumbricus rubellus Yang Dibudidayakan Dengan Pakan Limbah Organik, Journal SoilRens volume 1 no 1 Juli 2000 hal.24-28 
Esha, F. 2014. Manfaat dan Khasiat Cacing Tanah, http://indonesianherbal.blogspot.com/2014/03/manfaa t-dan-khasiat-cacing-tanah.html diakses tanggal 26 Februari 2015.

Herdian, H. 2010. Antibiotik Dari Tepung Cacing Tanah (Lumbricus rubellus) Sebagai Pemacu Pertumbuhan (growth promotor) Pada Ayam Broiler Menggunakan Metode Enkapsulasi,
Laporan Penelitian. Yogyakarta: Lembaga IImu Pengetahuan Indonesia (LIPI).

Toto, W. dan Jumsih. 2000. Pertumbuhan dan Perkembangan Lumbricus rubellus yang dibudidayakan dengan Enam Pakan Limbah Organik. Journal SoilRens, Vol. 1 No 2 Desember 2000, 61-67. 